\title{
Nilai Hematologi Total Eritrosit dan Kadar Hemoglobin Sapi Bali dengan Pakan Hijauan Organik
}

\section{(HEMATOLOGICAL VALUE OF TOTAL ERYTHROCYTES AND HEMOGLOBIN LEVEL OF BALI CATTLE WITH ORGANIC FORAGE FEED)}

\author{
Anak Agung Istri Ananda Septiarini ${ }^{1 *}$, Ni Ketut Suwiti ${ }^{1}$, I Gusti Ayu Agung Suartini ${ }^{2}$ \\ ${ }^{1}$ Laboratorium Histologi Fakultas Kedokteran Hewan Universitas Udayana, Bali \\ Jln. PB. Sudirman Denpasar-Bali; \\ ${ }^{2}$ Laboratorium Biokimia, Fakultas Kedokteran Hewan, Universitas Udayana, Bali \\ Jln. PB. Sudirman Denpasar-Bali. \\ *Email: gungananda02@gmail.com
}

\begin{abstract}
Abstrak
Hijauan organik telah menjadi pilihan pakan sapi bali di Bali, sehingga perlu diketahui pengaruhnya terhadap rerata total eritrosit dan kadar hemoglobin sapi bali. Penelitian ini menggunakan sepuluh sampel sapi bali betina umur umur 12-18 bulan. Sampel darah diambil melalui vena jugularis menggunakan venoject. Pemeriksaan total eritrosit dan kadar hemoglobin sapi bali diukur dengan alat Veterinary Hematology Analyzer. Hasil penelitian menunjukkan rerata total eritrosit yaitu $6,54 \times 10^{6} \mu 1$ dan rerata kadar hemoglobin $12.2 \mathrm{~g} / \mathrm{dL}$. Total eritrosit dan kadar hemoglobin sapi bali dengan pakan hijauan organik masih berada dalam kisaran normal.
\end{abstract}

Kata kunci: Sapi bali; hijauan; eritrosit; hemoglobin.

\begin{abstract}
Organic forage has become the choice of bali cattle feed in Bali, so it is necessary to know its effect on the total erythrocytes average and hemoglobin levels of bali cattle. This study used ten samples of bali cattle aged 12-18 months. Blood samples were taken through the jugular vein using venoject. Total erythrocyte examination and hemoglobin levels of bali cattle were measured using a Veterinary Hematology Analyzer. The results showed that the mean total of erythrocytes was $6.54 \times 106 \mu 1$, and the mean hemoglobin level was $12.2 \mathrm{~g} / \mathrm{dL}$. Total erythrocytes and hemoglobin levels of Balinese cattle with organic forage were still in the normal range.
\end{abstract}

Keywords: Bali cattle; organic feed; erythrocytes; hemoglobin.

\section{PENDAHULUAN}

Sapi bali (Bos sondaicus) merupakan sapi lokal hasil domestikasi dari banteng liar (Bibos banteng) (Hardjosubroto dan Astuti, 1993). Sapi bali dapat memanfaatkan pakan lokal yang berkualitas rendah, serta mampu beradaptasi dengan lingkungan lembab atau tropis dan tahan menghadapi serangan parasit (Kusuma et $a l, 2008)$. Permasalahan yang muncul saat ini adalah keterbatasan sumber pakan pada musim kering, sehingga sapi bali tidak dapat mengekspresikan potensi genetiknya secara optimal (Kusuma et al, 2008).
Sapi bali membutuhkan pakan berserat untuk kelangsungan hidupnya. Pakan berserat ini berupa hijauan seperti rerumputan dan dedaunan. Hijauan pakan ternak adalah tumbuhan yang dapat dimakan dan diberikan kepada ternak (Besung et al., 2019). Pemilihan hijauan pakan ternak harus diperhatikan, disukai ternak dan tidak mengandung toxin yang dapat membahayakan perkembangan ternak. Peternak sapi bali di Bali sudah ada yang menerapkan pemeliharaan berbasis pakan organik yakni lokasinya terletak di Desa Bulian Kecamatan KubutambahanBuleleng. Pakan tersebut berasal dari rumput limbah buah naga tanpa 
menggunakan tambahan peptisida atau bahan kimia lainnya. Rumput yang digunakan adalah rumput yang sedikit layu atau sedikit kandungan klorofil dan berasal dari lingkungan tempat pemeliharaan. Pemberian pakan hijauan organik pada sapi bali tanpa tambahan bahan kimia atau feed additive maupun feed supplement. Pakan berbasis organik dikhawatirkan berpengaruh pada sistem pertahanan tubuh ternak dan menyebabkan kerentanan sapi bali terhadap penyakit meningkat (Susetyo 1968). Salah satu indicator kerentanan tersebut, dapat dilihat dari profil darah.

Darah merupakan salah satu parameter sistem imun yang menentukan status kesehatan hewan, karena darah mempunyai komponen yang berfungsi sangat penting dalam pengaturan fisiologis tubuh (Mulyadi, 2015). Faktor yang dapat berpengaruh terhadap parameter hematologi darah adalah penyakit, umur, jenis kelamin, ras, temperatur lingkungan, keadaan geografis (Mulyadi, 2015). Salah satu indikatornya dapat dilihat dari nilai hematologi yakni total eritrosit dan kadar hemoglobin. Total eritrosit adalah jumlah eritrosit di setiap sel darah merah yang dipengaruhi oleh gizi pakan yang diberikan kepada ternak. Kadar hemoglobin dalam darah menjadi salah satu parameter untuk mengukur keadaan anemia dari suatu individu hewan. Berdasarkan hal tersebut perlu dilakukan pengamatan terhadap hematologi sapi bali khususnya total eritrosit dan kadar hemoglobin.

\section{METODE PENELITIAN}

\section{Pengambilan sampel darah}

Whole blood diambil dari sepuluh ekor sapi bali betina umur 12-18 bulan, dari peternakan milik Bapak I Wayan Kantra di Desa Bulian, Kecamatan Kubutambahan, Kabupaten Buleleng. Pengambilan sampel dilakukan dengan cara direstrain, diambil dengan venoject mengandung Ethylene Diaminetetra Acetic Acid (EDTA), melalui vena jugularis.

\section{Pengukuran total eritrosit dan kadar hemoglobin}

Pemeriksaan sample darah dengan alat Hematology Analyzer, alat akan secara otomatis melakukan self check kemudian background check. Sampel darah harus dipastikan sudah homogen dengan antikoagulan. Selanjutnya tombol ikon new sampel ditekan, kemudian tombol next sampel ditekan setelah itu masukkan data sampel dan nama hewan yang akan diperiksa darahnya (sapi bali). Tabung sampel ditutup dan kemudian data sampel dan nama hewan yang akan diperiksa darahnya tabung diletakkan dibawah sampling nozzle sampai ujung jarum menyentuh dasar tabung tombol counting ditekan, sehingga jarum sampel akan tertarik kedalam instrument dan sampel secara otomatis akan diproses menggunakan hematology analyzer. Hasil akan muncul pada layar secara otomatis, mencatat hasil pemeriksaan.

\section{Analisis data}

Data berupa nilai hematologi dianalisis dengan deskriptif kuantitatif dengan menggunakan analisis statistika dasar.

\section{HASIL DAN PEMBAHASAN}

Hasil pemeriksaan total eritrosit dan kadar hemoglobin sapi bali, disajikan pada Tabel 1 dan Tabel 2.

Tabel 1 menunjukkan rerata total eritrosit sapi bali dengan pakan hijauan organik sebesar $6,54 \times 10^{6} \mu$ l. Total eritrosit terendah ditemukan pada sapi bali no. 5 sebesar $4,66 \times 10^{6} \mu 1$ dan total eritrosit tertinggi $8,83 \times 10^{6} \mu$ l pada sapi bali no. 2 .

Tabel 2 menunjukkan rerata kadar hemoglobin sapi bali dengan pakan hijauan organik sebesar $12.2 \mathrm{~g} / \mathrm{dL}$. Kadar hemoglobin terendah adalah 9,9 g/dL yang ditemukan pada sapi bali no. 1 dan no. 10 dan kadar hemoglobin tertinggi $15,8 \mathrm{~g} / \mathrm{dL}$ ditemukan pada sapi bali no. 4 dan no. 2 .

Total eritrosit pada grafik batang kisaran nilainya antara $4,66 \times 10^{6} \mu \mathrm{l}$ $8,83 \times 10^{6} \mu \mathrm{l}$ sedangkan untuk kadar hemoglobin antara 9,9 g/dL - 15,8 g/dL. 
Sapi bali yang memiliki kadar hemoglobin tinggi juga memiliki total eritrosit yang tinggi (Gambar 1).

Rerata total eritrosit sampel darah sapi bali yang dipelihara dengan pakan hijauan organik sebesar $6,54 \times 10^{6} \mu 1$. Kisaran nilai normal total eritrosit pada sapi bali non organik sesuai penelitian Roland et al.,

\begin{tabular}{c|c|c} 
sTabel 1 Total Eritrosit Sapi Bali yang diberi Pakan Hijauan Organik \\
\hline No Sampel & Total Eritrosit $\left(10^{6} \mu \mathrm{l}\right)$ & Nilai Normal \\
\hline SB 1 & 5,72 & \\
SB 2 & 8,83 & \\
SB 3 & 7,48 & \\
SB 4 & 7,32 & \\
SB 5 & 4,66 & $4,9-10 \times 10^{6} \mu 1$ \\
SB 6 & 6,42 & \\
SB 7 & 6,03 & \\
SB 8 & 7,18 & \\
SB 9 & 6,12 & \\
SB 10 & 5,72 & \\
\hline Total & 65,48 & \\
\hline Rata-Rata & $6,54 \times 10^{6} \mu 1$ & \\
\hline Standar Deviasi & 1,17734 & \\
\hline
\end{tabular}

Keterangan: SB= Sapi Bali (Roland et al., 2014).

Tabel 2. Kadar Hemoglobin Sapi Bali yang diberi Pakan Hijauan Organik

\begin{tabular}{|c|c|c|}
\hline No Sampel & $\begin{array}{c}\text { Kadar Hemoglobin } \\
(\mathrm{g} / \mathrm{dL})\end{array}$ & Nilai Normal \\
\hline SB 1 & 9,9 & \\
\hline SB 2 & 15,8 & \\
\hline SB 3 & 15,4 & \\
\hline SB 4 & 15,8 & \\
\hline SB 5 & 10,0 & $8,4-15 \mathrm{~g} / \mathrm{dL}$ \\
\hline SB 6 & 11,0 & \\
\hline SB 7 & 10,8 & \\
\hline SB 8 & 13,2 & \\
\hline SB 9 & 10,9 & \\
\hline SB 10 & 9,9 & \\
\hline Total & 122,7 & \\
\hline Rata-Rata & $12.2 \mathrm{~g} / \mathrm{dL}$ & \\
\hline Standar Deviasi & 2,53028 & \\
\hline
\end{tabular}

Sementara sapi bali di Aceh memiliki nilai eritrosit yang lebih tinggi yakni sebesar 7,54x106 $\mu 1$ (Mulyadiet al., 2015). Hasil pemeriksaan total eritrosit sapi bali
2014 yaitu 4,9-10x $10^{6} \mu 1$. Sapi bali dengan pakan hijauan organik menunjukkan total eritrosit lebih tinggi dibandingkan total eritrosit pada sapi bali yang berada di rumah potong hewan Pesanggaran dengan pakan hijauan non organik yaitu dengan nilai $5,2 \times 10^{6} \mu \mathrm{l}$ (Siswanto, 2011). 
yakni 4,66x $10^{6} \mu 1$. Hal tersebut kemungkinan dipengaruhi oleh faktor nutrisi dalam pakan, semakin baik nutrisi dalam pakan maka akan menunjukkan total eritrosit yang lebih baik (Mulyadiet al., 2015). Nutrisi dalam pakan seperti zat besi, $\mathrm{Cu}$, asam amino vitamin $\mathrm{B} 9$ dan vitamin B12 merupakan komponen penting yang berpengaruh pada jumlah eritrosit.

Tinggi dan rendahnya total eritrosit pada sapi bali dipengaruhi oleh beberapa faktor yaitu nutrisi dalam pakan seperti zat besi, $\mathrm{Cu}$, vitamin, dan asam amino (Frandson, 1996). Zat besi dalam tubuh berperan penting dalam berbagai reaksi biokimia, yaitu memproduksi sel darah merah. Sel darah merah sangat diperlukan untuk mengangkut oksigen ke seluruh jaringan tubuh. Zat besi (Fe) di dalam tubuh akan berikatan dengan protein dan membentuk ikatan $\mathrm{Fe}-\mathrm{S}$, dan menjadi residu sistein dalam protein ferodoksin. Dalam tubuh, sebagian Fe digunakan untuk proses metabolisme (Darmono, 2007). Kekurangan Fe banyak terjadi pada hewan yang cepat tumbuh dan hanya diberi air susu hal ini disebabkan kadar Fe dalam air susu rendah.

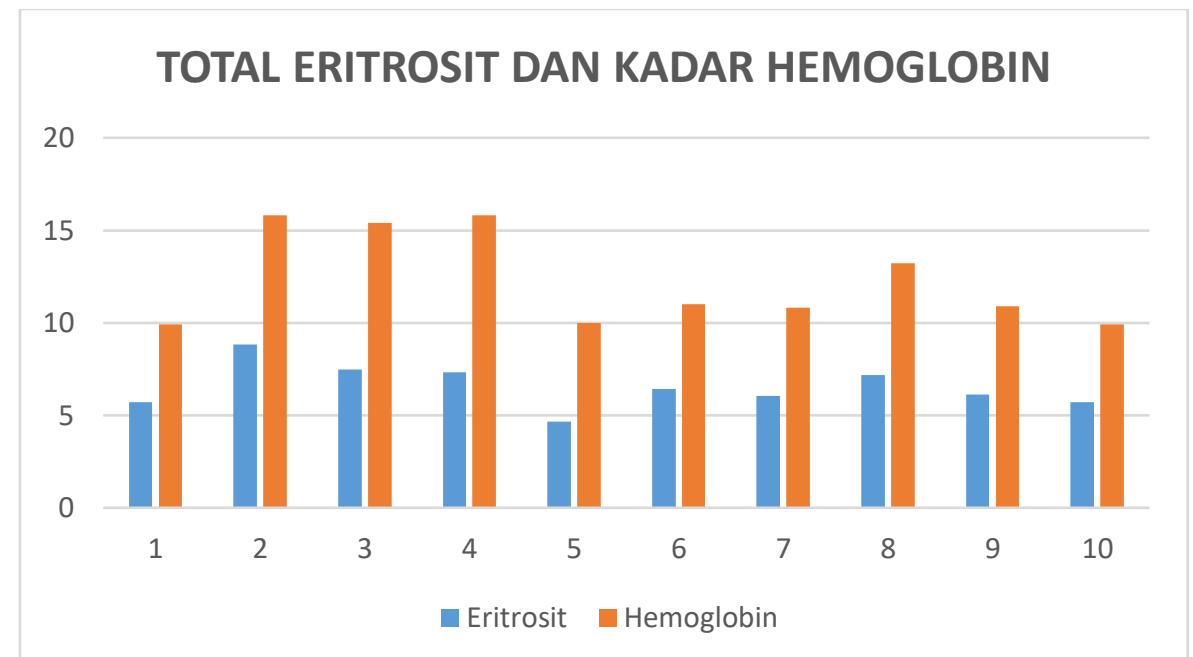

Gambar 1. Rerata Total Eritrosit dan Kadar Hemoglobin Sapi Bali Organik

Mineral besi dan tembaga memiliki sifat yang sama dalam sistem pembentukan darah (Besung et al., 2019). Mineral tembaga merupakan komponen dari berbagai enzim yang diperlukan untuk menghasilkan energi, anti oksidasi, dan sintesa hormon adrenalin serta untuk pembentukan jaringan ikat. Kekurangan dari mineral tembaga menyebabkan tidak berfungsinya sistem enzim, sehingga sistem metabolisme dan fisiologi tubuh tidak bekerja secara normal dan menyebabkan gangguan dalam pembentukan darah (Arifin, 1999).

Penggunaan vitamin pada ternak ruminansia yang diberi pakan hijauan jarang dilakukan karena hijauan sudah merupakan sumber berbagai macam vitamin. Untuk memenuhi kebutuhan vitamin pada ternak ruminansia, biasanya dicampurkan mineral-vitamin di dalam pakan konsentratnya. Bila pada ternak ruminansia terjadi difisiensi vitamin, hal ini dapat menyebabkan gangguan pertumbuhan dan perkembangan eritrosit (Suwandi, 2002). Selain diberikan vitamin hewan memerlukan protein sebagai sumber asam amino esensial dan (pada ruminansia) sebagai sumber nitrogen untuk mikrofolara rumen. Kualitas protein dalam pakan adalah tergantung pada profil asam amino dan daya cernanya (Yendraliza, 2013).

Total eritrosit pada ternak juga dipengaruhi oleh jenis kelamin. Nemeth et al. (2010) menyatakan bahwa perbedaan jenis kelamin pada hewan mamalia mempengaruhi jumlah eritrosit. Selain itu pada penelitian Zahrah (1990) menyatakan hewan jantan memiliki jumlah eritrosit yang lebih tinggi dibandingkan hewan 
betina. Perbedaan total eritrosit pada jenis kelamin kemungkinan disebabkan oleh iklim, lokasi dan ketersediaan jenis kualitas pakan (Tibo et al., 2004; Addas et al., 2010). Menurut Mohriet al. (2007), peningkatan total eritrosit seiring dengan pertambahan umur sapi. Laporan ini dikuatkan dengan pernyataan Brown dan Dellmann (1989), menyatakan, eritrosit diproduksi di sumsum tulang dan dilihat dari pertambahan umur sapi yang terus meningkat sehingga pada umur satu tahun eritrosit mulai stabil.

Mulyadi et al. (2015), menyatakan bahwa perbedaan total eritrosit sapi aceh dan sapi bali kemunginan disebabkan oleh perbedaan breed. Secara genetik, sapi aceh dan sapi bali memang memiliki perbedaan genetik. Menurut Handiwirawan dan Subandryo (2004), sapi bali (Bibos sondaicus) yang ada saat ini diduga berasal dari hasil domestikasi banteng liar (Bibos banteng) sedangkan sapi aceh merupakan turunan dari sapi zebu (Bos indicus) (Abdullah, 2008). Perbedaan genetik dari kedua sapi inilah diduga menyebabkan perbedaan total eritrosit pada kedua jenis bangsa sapi tersebut.

Faktor lain yang mempengaruhi nilai total eritrosit adalah suhu lingkungan dalam sistem pemeliharaan, karena berperan terhadap jumlah sel darah merah pada hewan. Temperatur tubuh yang tinggi menyebabkan proses metabolisme menjadi semakin meningkat dan mengakibatkan kinerja eritrosit lebih tinggi sehingga sel darah merah cepat mati. Faktor-faktor lingkungan yang sering berfluktuasi, baik yang bersifat harian maupun musiman kemungkinan ditemukan dalam kondisi yang ekstrim. Perubahan pada kualitas lingkungan seperti perubahan iklim, polusi zat kimia dan fluktuasi pencemaran alam bisa menyebabkan hewan menjadi stres dan lemah sehingga dapat mengalami perubahan fisiologi darah (Omonona and Ekpenko, 2011).

Kadar hemoglobin sapi bali dengan pakan hijauan organik memiliki rerata sebesar 12,2 g/dL. Kadar hemoglobin tersebut masih dalam kisaran normal. Kisaran normal kadar hemoglobin 8,4-15 $\mathrm{g} / \mathrm{dL}$ (Roland et al., 2014). Sapi yang dipelihara berbasis organik memiliki nilai rerata lebih tinggi dibandingkan dengan sampel sapi bali yang berada di rumah potong hewan yang memiliki kadar hemoglobin 8,7 g/dL (Siswanto, 2011). Hasil pemeriksaan kadar hemoglobin sapi bali dengan pakan hijauan organik menunjukkan nilai tertinggi pada sampel no. 2 yakni $15,8 \mathrm{~g} / \mathrm{dL}$, sedangkan total eritrosit terendah terlihat pada sampel no. 1 dan no. 10 yakni 9,9 g/dL. Hewan yang memiliki kadar hemoglobin tinggi dipengaruhi oleh sistem pemeliharaan dan kondisi kandang yang terbuka sepanjang hari sehingga mendapatkan oksigen yang cukup.

Faktor lain yang mempengaruhi kadar hemoglobin adalah nutrisi dalam pakan. Kadar hemoglobin sapi bali dengan pakan hijauan organik pada no. 1 dan no 10 mengalami penurunan hal ini kemungkinan disebabkan oleh faktor internal. Kadar hemoglobin akan meningkat apabila sapi dalam keadaan stres, hal ini disebabkan karena dilepaskannya adrenalin dan epineprin/norepineprin sehingga tekanan darah meningkat, akibatnya laju eritrosit pun meningkat (Suwandi, 2002).

Pakan yang berbasis otrganik memungkinkan terjadi kekurangan zat besi (Fe) sehingga proses pembentukan hemoglobin menjadi terganggu. Mandal dan Dass (2010) mengatakan, suplmentasi $\mathrm{Zn}$ sangat penting untuk meningkatkan status kadar hemoglobin yang lebih baik. Kadar hemoglobin berbeda-beda pada berbagai tingkat pertumbuhan. Menurut Laurent dan Brisson (1988), sapi masa pertumbuhan yang disuplementasi dengan zat besi memiliki kadar hemoglobin yang lebih tinggi dibandingkan dengan yang tidak disuplementasikan zat besi

Faktor aktivitas tubuh juga dapat berpengaruh pada kadar hemoglobin. Swenson (1993) menyatakan, makin tinggi 
aktivitas tubuh makin tinggi pula kadar hemoglobinnya. Rendahnya kadar hemoglobin menyebabkan aktivitas tubuh pada sapi turun. Zat besi dalam hemoglobin, ketika jumlahnya berkurang, secara ekstrim dapat mengubah aktivitas kerja dengan menurunkan transpor oksigen (Swenson 1993).

\section{SIMPULAN DAN SARAN}

\section{Simpulan}

Hematologi darah sapi bali yang dipelihara dengan pakan organik masih dalam niai yang normal. Rerata nilai eritrosit sapi bali yang diberikan pakan organik sebesar $6,54 \times 10^{6} \mu \mathrm{l}$ dan kadar hemoglobinnya $12.2 \mathrm{~g} / \mathrm{dL}$.

\section{Saran}

Pemeliharaan sapi bali dengan diberi hijauan organik dapat dipertahankan, hal ini dikarenakan tidak mengganggu nilai hematologi khususnya total eritrosit dan hemoglobin sapi bali.

\section{UCAPAN TERIMA KASIH}

Penulis mengucapkan terimakasih kepada Bapak Dekan Fakultas Kedokteran Hewan atas fasilitas yang telah diberikan selama penelitian dan kepada semua pihak yang telah membantu dalam penelitian ini, sehingga penelitian ini dapat diselesaikan dan semoga bermanfaat bagi masyarakat.

\section{DAFTAR PUSTAKA}

Abdullah MAN. 2008. Karakterisasi genetik sapi aceh menggunakan analisis keragaman fenotip, daerah $d-$ loop dna mitokondria dan dna mikrosatelit. IPB. Bogor.

Addass PA, Midau A, Babale DM. 2010. Haemato-biochemical findings of indigenous goats in mubi adamawa state Nigeria. J. Agric. Soc. Sci., 6: 1416.

Besung INK, Watiniasih NL, Mahardika GNK, Agustina KK, Suwiti NK. 2019. Mineral levels of bali cattle (Bos javanicus) from four different type of land in different rearing areas. Biodiversitas, 20(10): 2931-2936.
Darmono. 2007. Penyakit defisiensi mineral pada ternak ruminansia dan upaya pencegahannya. J. Litbang Pertanian, 26(3): 104-108.

Handiwirawan E, Subandryo. 2004. Potensi keragaman sumber daya genetik sapi Bali. Wartazoa, 14(3): 107-115.

Kusuma D, Atien P. 2008. Keberhasilan pemanfaatan sapi bali berbasis pakan lokal dalam pengembangan usaha sapi potong di Indonesia. Wartazoa. 18(1): 34-45.

Mulyadi A. Triya ML, Barradillah A, Nuzul A, Muttaqien, Fakhrurrazi. 2015. Jumlah eritrosit dan nilai hematokrit sapi aceh dan sapi bali di Kecamatan Leumbah Seulawah Kabupaten Aceh Besar. J. Med. Vet. 9(2): 115-118.

Mohri M, Sharifi K, Eidi S. 2007. Hematology and serum biochemistry of Holstein dairy calves: age related changes and comparison with blood composition in adults. J. Vet. Scin., 83: 30-39.

Nemeth NF, Kiss I, Furka I, Miko. 2010. Gender differences of blood rheological parameters in laboratory animals. Clin. Hemorheol. Microcircul., 45(6): 263272.

Roland L, Drillich M, Iwerse M. 2014. Hematology as a diagnostic tool in bovine medicine. J. Vet. Diagnos. Invest. 26(5): 592-598.

Siswanto. 2011. Gambaran sel darah merah sapi bali (Studi rumah potong). Buletin Vet. Udayana. 3(2): 99-105.

Suwandi. 2002. Manfaat Pemeriksaan Gambaran Darah Umum Pada Ternak Ruminansia. Balai Penelitian Ternak. Bogor.

Tibbo MY, Jibril M, Woldemeskel F, Dawo K, Aragaw. 2004. Factors affecting hematological profiles in three ethiopian indigenous goat breedy. Intern. J. Appl. Res. Vet. Med., 2(4): 297-309.

Yendraliza. 2013. Pengaruh nutrisi dalam pengelolaan reproduksi ternak (Studi literatur). Kutubkhanah, 16(1): 20-26. 